\title{
LEARNING WITH KAHOOT! AS ADVANTAGEOUS LEARNING EXPERIENCE IN EFL CLASSROOM
}

\author{
Doni Alfaruqy \\ doni.alfaruqy@staff.itera.ac.id \\ Institut Teknologi Sumatera, Indonesia, \\ Harits Setyawan \\ harits.setyawan@dkv.itera.ac.id \\ Institut Teknologi Sumatera, Indonesia,
}

\begin{abstract}
Kahoot! as game-based student response system has been widely used for new virtual learning experience. On the other hand, the impacts of Kahoot! in learning EFL for university students have not been investigated yet. The objective of this study is to describe students' perceptions towards the use of Kahoot! in learning EFL and explore students' learning virtual experience by using Kahoot!. The research method used is qualitative method with data collection technique by using observation techniques and documentation techniques. Interviews were done to collect students' perceptions. Furthermore, the benefits of using Kahoot! and description of activities in Kahoot! have been observed. The result of analysis revealed that students have positive learning experience toward Kahoot!. As a result, Kahoot! can be used as additional learning application for reviewing the materials and motivating students to learn English.
\end{abstract}

Keywords: Kahoot!, virtual learning, EFL classroom

\section{INTRODUCTION}

Pandemic covid-19 has changed the situation of teaching and learning process into virtual learning. This condition becomes difficult task for teachers to keep students' motivation and concentration during online learning process. Lack of motivation can influence the result of learning and create a negative classroom atmosphere (O.L.Liu, Bridgeman, and Adler, 2012).
Nowadays, this situation for EFL teachers needs to design comfortable and interesting learning media. Kahoot! can be one of alternative learning applications which creates students in becoming motivated (Asa'd and Gunn, 2018). This application makes teachers can provide various media of learning with fun situation. It is equipped with colorful background, audio music, points or scoring, interesting graphics and also at the 
end of game, there is a standing podium for the winners. Also, teachers can get informal feedback or response related to the questions given.

Having taught critical reading $(M K U$ Bahasa Inggris) as compulsory subject for more than 3 years for the first-year students of ITERA has made the writers curious to investigate the result of learning English through using Kahoot! for students' attitude. As the objective of this subject is to make students think critically about their reading materials in which consists of prereading, reading and post-reading.

The implementation of Kahoot! in critical reading class, hopefully, can create new learning experience for students. It will help them to understand the materials better. There is plethora of studies related to the use of Kahoot! towards students' motivation and achievement.

Wang and Lieberoth (2016) state that using Kahoot! can influence students' motivation, concentration, engagement and enjoyment because there are audio and points for students during learning. In line with that, Hazwani et all (2018) researched
Biomedical engineering by using quantitative research method which found that there is a significant result about students' engagement by using Kahoot in English class.

A research by Halise (2018) cited in Nikmah (2019) conducted the research about "the implementation of the digital assessment tool 'Kahoot!" at elementary school in Turkey by using descriptive qualitative technique which concluded that most of students became "satisfied" with this application. This argument also is supported by Ismail, et al (2018) who stated that Kahoot! can improve students' motivation and enjoyment during learning process.

From the previous studies, the writers believe that there is a gap between theoretical and practical. The writers assume about the effect of using Kahoot! towards university students' attitude in learning English, especially learning of critical reading. Therefore, the writers want to investigate students' perceptions toward their learning experience in using Kahoot! with critical thinking in EFL classroom. 


\section{REVIEW OF RELATED LITERATURES}

\section{Kahoot!}

Kahoot has been played for more than 250 million games and with over 1.5 billion participating players in 200 countries for the last 12 months (source: Kahoot.com). It means that there are many benefits from Kahoot! which can make it so popular among learners and teachers. The writers choose Kahoot! as learning media for EFL context because of some rationales, the first, Kahoot! provides quizzes which can insert texts, videos, and pictures with music and audio. Next, the teachers can set the time duration for quiz so the teacher will easily monitor students' progress. The third benefit, the teacher can check students' understanding which is related to the material given. It can be known by the number of students who can answer correctly and which one of question items was very difficult to answer. All of these activities can be taken as a part of learning evaluation.

Students also get the benefits from Kahoot!, the first one is to increase their motivation, engagement, excitement, and new learning experience (Licorish,et all 2018). Second, the students are involved more in playing Kahoot! than using other learning applications. As a result, it improves their concentrations on learning new materials. Lastly, this application creates a new learning experience for students because they learn English by using games based response that is Kahoot!. It will make a good impression for students that learning English can be done with fun and easy way.

\section{Critical Thinking}

Critical thinking means the ability of understanding language contextually to comprehend sentences, sensitivity, emotion, and feeling and also openness to produce creative thinking (Cohen, 2015). It shows that critical reading can trigger students to be creative in solving their problems, especially in understanding reading texts.

Critical thinking is an important skill to be learned by students. It can be inserted in English materials through teaching critical reading strategies. As stated by Maslakhatin (2016), equipping students with critical reading strategies will help them in understanding the text meaningfully. Therefore, critical reading materials can be taught in fun conditions through using Kahoot!. 


\section{METHODS}

Qualitative research is used in this study. The data obtained had to be meaningful, specific, and meaning making. Qualitative content analysis focuses on collecting the data in qualitative research which can be drawn from observations, interviews, and group discussion (Leavy, 2017).

The data of this study were collected by using online observation, interviews, and group discussion. The researchers who taught different classes took the data in sequence. They did observation, interviews and group discussion in their classes. Then, they reported the data to be analysed.

To analyse the data, the researchers deployed students' daily reports in Kahoot!, interviews, and survey (both open-ended and closed-ended questions). The validity of the research data was proven through various participants' study

\section{RESULTS AND DISCUSSION}

Students' Perceptions towards Kahoot! in EFL classroom

The use of Kahoot! in a teaching learning process is so challenging for students. programs. 132 students on the second semester from 21 students from electrical engineering, 10 students from mathematics, 12 students from biology, 15 students from geophysics engineering, 24 students from pharmacy, 20 students from mining engineering, 13 students from chemistry and 17 students from civil engineering. This study was done through using online meeting ( $\mathrm{g}$-meet and g-form) at Institut Teknologi Sumatera (ITERA).

The data of this study were analysed by using students' scale reports, interviews and survey. Students' scale reports can be seen in Kahoot! system reports, interviews were done by using google meets in order to get deep understanding, then, surveys were conducted by using google form.

Using Kahoot! for virtual learning will be so helpful for teachers. The researcher took some students randomly to do deeper 
interview which related to the use of Kahoot! to help students in learning.

Students' opinions towards Kahoot! are very positive for helping students to understand the materials. They can get more explanation about the materials which have been explained previously. As shown in the following extract. Here are. "it was so helpful to understand the materials in the class"

"Kahoot was beneficial to review the materials"

From the extract above, the students feel so advantageous in using Kahoot! to get clearer understanding. The teacher can use Kahoot! after giving the materials to check students' understandings. This finding had been supported by Wichadee and Pattanapichet, (2018) who found that Kahoot! can be used to review the learning at the end of the lessons. The teachers optimized Kahoot! to provide more explanations about students' confusion in comprehending the materials. It showed that Kahoot! is seen as meaningful way in teaching-learning process. This finding was in line with Chaiyo and Nokham (2017) who believed that Kahoot! can improve students' concentration, understanding, enjoyment and engagement during the class.

\section{The Function of Kahoot! for Students in}

\section{EFL classroom}

After getting positive response from students' view, Kahoot! also has important role for students in EFL classroom. Teachers can create their own content or materials by using Kahoot!. Nkhoma, et all (2019) stated that Kahoot! can provide feedbacks, check students' understanding and engage students in large class. Other advantages can play quiz, assess the students and also join games without registration for students. The important point is by using Kahoot! which can affect students' engagement, concentration, motivation, and enjoyment. As shown by the following extract, here are as follow.

"Kahoot makes us become motivated because we have to answer questions quickly and correctly"

"It makes our lesson so happy and challenging"

"It helps to improve our focused and understanding the materials" 
"Kahoot creates fun and enjoyable learning experience”

"We can get direct feedback about our answer whether it is true or not"

"It helps to think critically because we should answer the questions in Kahoot correctly and quickly so that we need to think critically."

"Kahoot can be used to evaluate the materials which have been explained previously"

From the extracts above, Kahoot! has positively affected students' motivations and concentrations in understanding the materials for $\mathrm{EFL}$ classroom. The content of materials in Kahoot! has been adjusted with students' topics which is discussed in learning process. Therefore, they became interested in answering questions for Kahoot!.

The combination between teacher's explanations and Kahoot! provided enjoyable learning process. The lecturer can give more detailed explanation by using questions or examples in Kahoot!

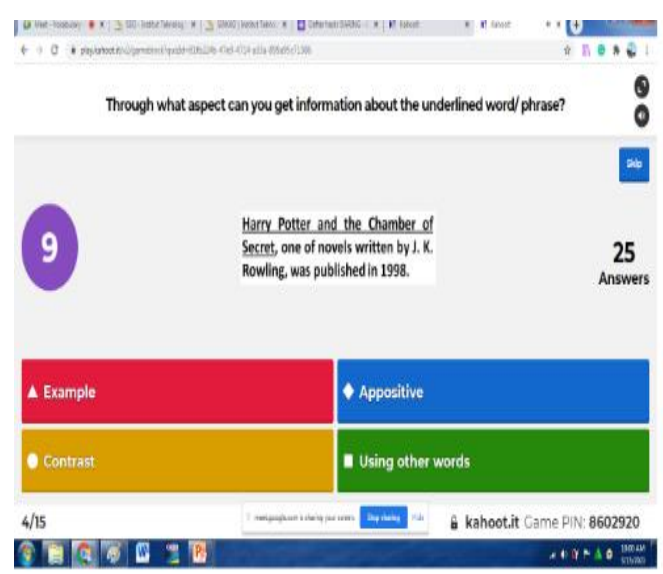

Figure 1. Example of question in Kahoot!

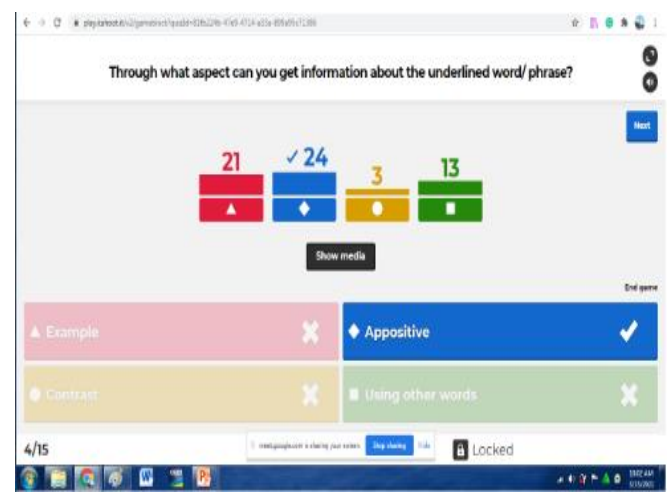

Figure 2. Students' answer results

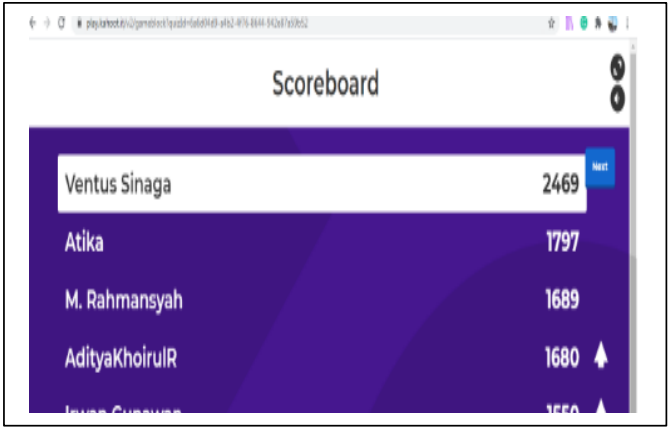

Figure 3. Students' scores 


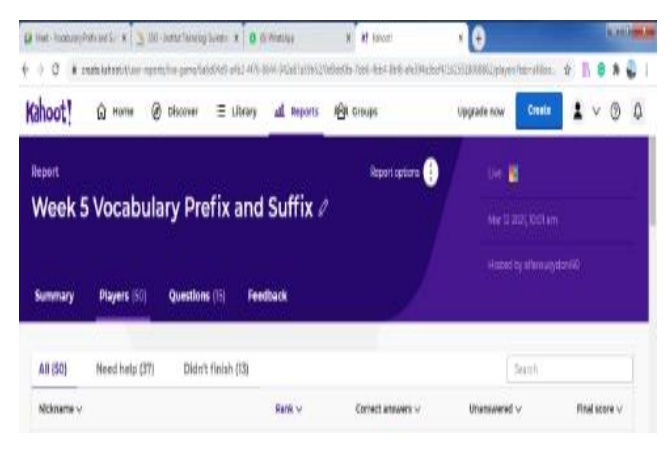

Figure 4. Students' summary score

From the observation of implementing Kahoot! in virtual learning process, it can be seen that Kahoot! can be used for engagement, assessment, and evaluation

\section{CONCLUSION \& SUGGESTION}

Learning with Kahoot! has positive impacts on students' motivation, concentration, enjoyment and engagement. It can be shown from students' responses. 90, 90\% students agreed that learning with Kahoot! is more interesting, fun and challenging than conventional learning media. Kahoot! affects positively students' learning results but, there are some rooms for improvements, such as requiring good internet signal, two devices (smartphone and laptop) for optimal result, and time limitation. for learning process. This finding was supported by Anotniou, Mbah, \& Parmaxi, (2016); Ismail \& Mohammad, (2017); Leung \& Pluskwik, (2018); Licorish, et al., (2018); Zarzycka-Piskorz, (2016) who found that Kahoot! positively influenced the engagement, the excitement, learning experience and evaluation. Students also can feel fun learning experience by using Kahoot! because there are active participations and interactions between lecturer and students.

English lecturers should use this learning application to provide advantageous learning experience for students. Kahoot! application can be used at the beginning, middle or at the end of the lesson to engage students' concentration and it based on teachers' need. As a result, it can be used for lecturers to deliver the materials effectively and check students' understanding. In short, Kahoot! has been useful learning tool for students. 


\section{REFERENCES}

Antoniou, K., Mbah, E., \& Parmaxi, A. 2016. Teaching Turkish in low tech contexts: Opportunities and Challenges. Eurocall, 32.

Asa'd, R., \& Gunn, C. 2018. Improving problem solving skills introductory physics using Kahoot! Physics Education, 53 (5), 053001

Chaiyo,Y., \& Nokham, R. 2017. The effect of Kahoot!, Quizizz and Google Forms on the student's perceptions in the classrooms response system. In Digital arts, media, and technology (ICDAMT), international conference on (pp.178-182). IEEE.

Cohen, Martin. 2015. Critical Thinking Skills for Dummies. Chichester, West Sussex : John Wiley \& Sons, Ltd.

Muhridza, Nur Hazwani Mohd, Nur Afifah Mohd Rosli, Azura Sirri, and Adlina Abdul Samad. 2018. "Using Game-Based Technology, KAHOOT! For Classroom Engagement." LSP International Journal, 5 (2).

Nkhoma, C., Nkhoma, M., Thomas, S., Tu, L.,K., \& Le, N.,Q. 2019. Gamifying A Flipped First Year Accounting Classroom Using Kahoot! International Journal of Information System and Engineering, (6(1).

Ismail, M.A.-A., \& Mohammad, J.A.-M. 2017. Kahoot!: A Promising tool for Formative Assessment in Medical Education. Education in Medicine Journal, 9 (2)

Ismail, M. E., N. Sa'adan, M. A. Samsudin, N. Hamzah, N. Razali, and I. I. Mahazir. 2018. Implementation of The Gamification Concept Using KAHOOT! Among TVET Students: An Observation.” Journal of Physics: Conference Series 1140: 012013.

Leavy, Patricia. 2017. Research Design: Quantitative, Qualitative, Mixed Methods, ArtsBased, and Community-Based Participatory Research Approaches. The Guilford Press.

Leung, E., \& Pluskwik, E. 2018. Effectiveness of Gamification Activities in a Project-Based Learning Classroom. International Journal of Educational Technology in Higher Education, 15(41)

Licorish, S.A., Owen, H.E., Daniel, B., \& George, J.,L. (2018). Students' Perception of Kahoot!'s influence on Teaching and Learning. Research and Practice in Technology Enhanced Learning, 13 (1), 9

Maslakhatin, M. (2017). Critical Reading Strategies to Foster Students Critical Thinking. Buana Pendidikan: Jurnal Fakultas Keguruan Dan Ilmu Pendidikan, 12(22), 99 - 110. https://doi.org/10.36456/bp.vol12.no22.a621 
Nikmah, Hadirotun. 2020. Gamification to Improve Students' Engagement in Learning English. Proceeding of 1stConference of English Language and Literature (CELL) 2 (1): 60-70.

Liu, Ou Lydia, Brent Bridgeman, and Rachel M. Adler. 2012. Measuring Learning Outcomes in Higher Education: Motivation Matters. Educational Researcher. 41 (9): 352-62.

Wang, Alf, and Andreas Lieberoth. 2016. The Effect of Points and Audio on Concentration, Engagement, Enjoyment, Learning, Motivation, and Classroom Dynamics Using Kahoot!. 10th European Conference on Game Based Learning (ECGBL 2016)

Wichadee, S., \& Pattanapichet, F. 2018. Enhancement of performance and motivation through application of digital games in an English language class. Teaching English with Technology, 18(1), 77-92.

Zarzycka-Piskorz, E. 2016. Kahoot it or not? Can Games be Motivating in Learning Grammar?. Teaching English with Technology, 16(3), 17-36

https://kahoot.com/company/ accessed at $1^{\text {st }}$ April 2020, at 4:22 PM 